\title{
Evaluation of the correlation of vasculogenic mimicry, ALDH1, KAI1 and microvessel density in the prediction of metastasis and prognosis in colorectal carcinoma
}

Bo Zhu', Lei Zhou', Lan Yư , Shiwu Wu*, Wenqing Song, Xiaomeng Gong and Danna Wang

\begin{abstract}
Background: Metastasis and recurrence are the most common reasons for treatment failure of colorectal carcinoma (CRC). Vasculogenic mimicry (VM, blood supply formation often seen in highly aggressive tumors), Aldehyde dehydrogenase 1 (ALDH1, a biomarker of cancer stem cells), KAl1 (a suppressor gene of tumor metastasis) are all valuable factors for metastasis and prognosis in diverse human cancers. However, the correlation of VM, ALDH1, KAl1 and microvessel density (MVD) in CRC is unclear. In this study, we analyzed the correlations among VM, ALDH1, KAl1 and MVD, as well as their respective correlations with clinicopathological parameters and survival in CRC.

Methods: The level of VM, ALDH1, KAl1 and MVD in 204 whole tissue samples of CRC were examined by immunhistochemistry. Clinical data was also collected.

Results: Levels of VM, ALDH1 and MVD were significantly higher, and levels of KAl1 significantly lower, in CRC tissues than in normal colorectal tissues. Levels of VM, ALDH1 and MVD were positively associated with invasion of depth, lymph node metastasis (LNM), distant metastasis and tumor-node-metastasis (TNM) stages, and negatively with patients' overall survival (OS). Levels of KAl1 was negatively correlated with invasion of depth, LNM, distant metastasis and TNM stages, and the KAl1 positive expression subgroup had significantly longer OS than did the KAl1- subgroup. In multivariate analysis, high levels of VM, ALDH1 and KAl1, as well as TNM stages were independently correlated with lower OS in patients with CRC.
\end{abstract}

Conclusions: VM, MVD and the expression of ALDH1 and KAl1 may represent promising metastatic and prognostic biomarkers, as well as potential therapeutic targets for CRC.

Keyword: CRC, VM, ALDH1, KAl1, MVD, Prognosis

\footnotetext{
* Correspondence: 573448542@qq.com

${ }^{\dagger}$ Equal contributors

Department of Pathology, the First Affiliated Hospital of Bengbu Medical

College, Bengbu Medical College, No.287, Changhuai Road, Bengbu, Anhui

Province, China
} 


\section{Background}

In 2012, colorectal cancer (CRC) was reportedly found in about 1.4 million and accounted for approximately $10 \%$ of all new cancer cases, making it the third most commonly diagnosed cancer in the worldwide [1]. The increase in China may reflect an increased prevalence of risk factors for CRC, such as unhealthy diet, obesity and smoking $[2,3]$. In China, majority of patients diagnosed with CRC have advance stage cancer and are unsuitable for curative therapy.

The most common reasons for cancer treatment failure are metastasis and recurrence. This may be related to a small population of tumor cells which named as cancer stem cells (CSC) or tumor initiating cells (TIC). CSC has the capacity to self-renew and give rise to progression and differentiation in various human solid tumors [4-7]. CSC has been isolated from various tumor entities and related to therapeutic (chemo- or radioresistance) resistance and poor prognosis. Aldehyde dehydrogenases (ALDHs), also known as a family enzymes, which can be found in the mitochondria, nucleus and cytoplasm [8]. The ALDH enzymes can modulate several fundamental biological functions, such as proliferation and differentiation, as well as the cell response to oxidative stress. ALDH1, which is an important member of ALDH family enzymes, is considered as a marker for CSC. The function of ALDH1 is to detoxify and metabolize various endogenous and exogenous aldehydes, as well as oxidize retinol to synthesize retinoic acid [9]. Overexpression of ALDH1 may increase the risk of alcohol-linked cancers [10]. Furthermore, ALDH1 has been considered as a useful marker for metastasis and poor prognosis in various malignant tumors, including pancreatic cancer, esophageal cancer, lung cancer and gastric cancer [11-14].

Angiogenesis may also be related to metastasis and recurrence. Microvessel density (MVD) is one of the most commonly indicators for assessing the activity of angiogenesis. However, the role of MVD that predicts prognosis was controversial in some studies $[15,16]$. Similar to the role, the clinical benefit of anti-angiogenic therapy for malignant tumors is still unsatisfactory [17]. It is critical to be addressed whether there were other mechanisms about tumor blood supply. In 1999, Maniotis et al. firstly reported vasculogenic mimicry (VM) [18], a new blood supply is a vascular channel-like structure that is lining of cancer cells. VM is consisted of three structures: highly aggressive cancer cells, rich extracellular matrix and vasculogenic-like channel to the host microcirculation system [19-22]. VM, as a supplementary theory of angiogenesis, may explain the failure of anti-angiogenic therapy [23, 24]. Recently, accumulating evidence has been suggested that VM should be considered as a valuable biomarker for metastasis and prognosis in various human cancers [25-29].
KAI1, also named as CD82, which is originally considered as a suppressor gene of metastasis in prostate cancer cells [30]. KAI1, which belongs to the tetraspanin superfamily (TM4SF), is located on chromosome 11p11.2 and contains 10 exons and 9 introns. It has been demonstrated that TM4SF protein could inhibit tumor metastasis [31]. KAI1 can inhibit tumor metastasis through promoting cell-cell or cell-extracellular matrix interactions [32]. KAI1 is also involved in some fundamental biological processes, including migration, adhesion, differentiation and invasion [33, 34]. KAI1 is also identified as a useful biomarker for metastasis and prognosis in diverse human cancers [35].

Overall, studies of ALDH1, VM, MVD and KAI1 in association to metastasis and prognosis suggested that these biomarkers should affect tumor progression. However, correlations among ALDH1, VM, MVD and KAI1 in CRC have not yet been widely reported. In this study,

Table 1 Patients characteristics

\begin{tabular}{|c|c|c|}
\hline Patients characteristics & Frequency $(n)$ & Percentage (\%) \\
\hline \multicolumn{3}{|l|}{ Gender } \\
\hline Male & 120 & 58.8 \\
\hline Female & 84 & 41.2 \\
\hline \multicolumn{3}{|l|}{ Ages } \\
\hline$<60$ & 81 & 39.7 \\
\hline$\geq 60$ & 123 & 60.3 \\
\hline \multicolumn{3}{|l|}{ Size } \\
\hline$<5.0 \mathrm{~cm}$ & 119 & 58.3 \\
\hline$\geq 5.0 \mathrm{~cm}$ & 85 & 41.7 \\
\hline \multicolumn{3}{|l|}{ Location } \\
\hline Colon & 99 & 48.5 \\
\hline Rectum & 105 & 51.5 \\
\hline \multicolumn{3}{|l|}{ Grade } \\
\hline Well & 45 & 22.1 \\
\hline Moderate & 107 & 52.5 \\
\hline Poor & 52 & 25.5 \\
\hline \multicolumn{3}{|l|}{ Invasion } \\
\hline Subserosa & 113 & 55.4 \\
\hline Visceral peritoneum & 91 & 44.6 \\
\hline \multicolumn{3}{|l|}{ Distant metastasis } \\
\hline No & 176 & 86.3 \\
\hline Yes & 28 & 13.7 \\
\hline \multicolumn{3}{|l|}{ Lymph node metastasis } \\
\hline No & 122 & 59.8 \\
\hline Yes & 82 & 40.2 \\
\hline \multicolumn{3}{|l|}{ TNM stage } \\
\hline land II & 125 & 61.3 \\
\hline III and IV & 79 & 38.7 \\
\hline
\end{tabular}


we verified the hypothesis that above biomarkers are mutual related and associated with metastasis and prognosis in CRC.

\section{Methods}

\section{Patients and tissue samples}

We collected samples from all 204 patients (median age: 59.4 years; range: $31-77$ years) who were treated for CRC at the Department of Pathology of the First Affiliated Hospital of Bengbu Medical College, from January 2007 to December 2010, along with 204 samples of the corresponding adjacent normal colorectal mucosa tissues (removed the same patient, from surrounding colorectal mucosa tissue at least $5 \mathrm{~cm}$ away from the cancer edge). Patients who had received preoperative chemo- or radiotherapy were excluded. All tissue specimens were obtained with patients writing consent and the study was approved by the ethical committee of the Bengbu Medical College and performed in accordance with the guidelines of the Declaration of Helsinki. We collected the entirely clinicopathological and follow-up data (at 6 months intervals by mail, phone or social application). Overall survival (OS) time was counted from the patients operation date to his/ her death date or January 2015 (mean OS: 51.6 months; range: 8-96 months). Grade of tumor differentiation was according to WHO (World Health Organization) standard. Tumor-node -metastasis stage was assessed according to the $7^{\text {th }}$ edition of the AJCC (American Joint Committee on Cancer). Other characteristics see Table 1.

\section{Immunohistochemistry}

Immunohistochemistry was conducted according to the guideline of Elivision ${ }^{\mathrm{Tx}}$ Plus detection kit instructions
(Lab Vision, USA). All CRC- and corresponding normal colorectal mucosa tissues were fixed in $10 \%$ buffered formalin and embedded in paraffin. Then continuous $4 \mu \mathrm{m}$ thick tissue sections were cut. All specimens were deparaffinized and dehydrated with xylene and graded alcohol, subsequently washed for $10 \mathrm{~min}$ with PBS (phosphate buffer solution, $\mathrm{pH}$ 7.2). Endogenous peroxidase activity was quenched by incubation of samples in methanol containing $3 \% \mathrm{H}_{2} \mathrm{O}_{2}$ for $10 \mathrm{~min}$ at room temperature (RT), then placed in citrate buffer ( $\mathrm{pH}$ 6.0) and heated to $95{ }^{\circ} \mathrm{C}$ for $30 \mathrm{~min}$ for antigen repair. After several washes with PBS, all samples were blocked with goat serum for $20 \mathrm{~min}$ at RT, then incubated with mouse monoclonal antibody against human ALDH1 (Abcam, USA) or CD34 (Abcam, USA) or KAI1 (Abcam, USA) for $1 \mathrm{~h}$ at $37{ }^{\circ} \mathrm{C}$. Microvessel density (MVD) was determined by the number of small CD34 positive vessels counted. All sections were performed periodic acid-Schiff (PAS) -CD34 dual staining to characterize endothelial cells in glycosylated basement membranes of vessels, as well as vasculogenic-like structures [19]. Furthermore, there was no necrosis or hemorrhage near the VM channels in cancer tissues. All samples were counterstained with hematoxylin, dehydrated, airdried and mounted. The method was adopted from Weidner et al. with some modifications to assess the MVD of CRC [36]. A modified Yue's method was used to evaluate the VM of CRC [37]. ALDH1 positive staining was mainly confined in the cytoplasm of cancer cells; KAI1 positive staining was mainly confined in the membrane and cytoplasm of cancer cell. Negative controls were prepared by leaving out primary antibodies from the staining procedure.

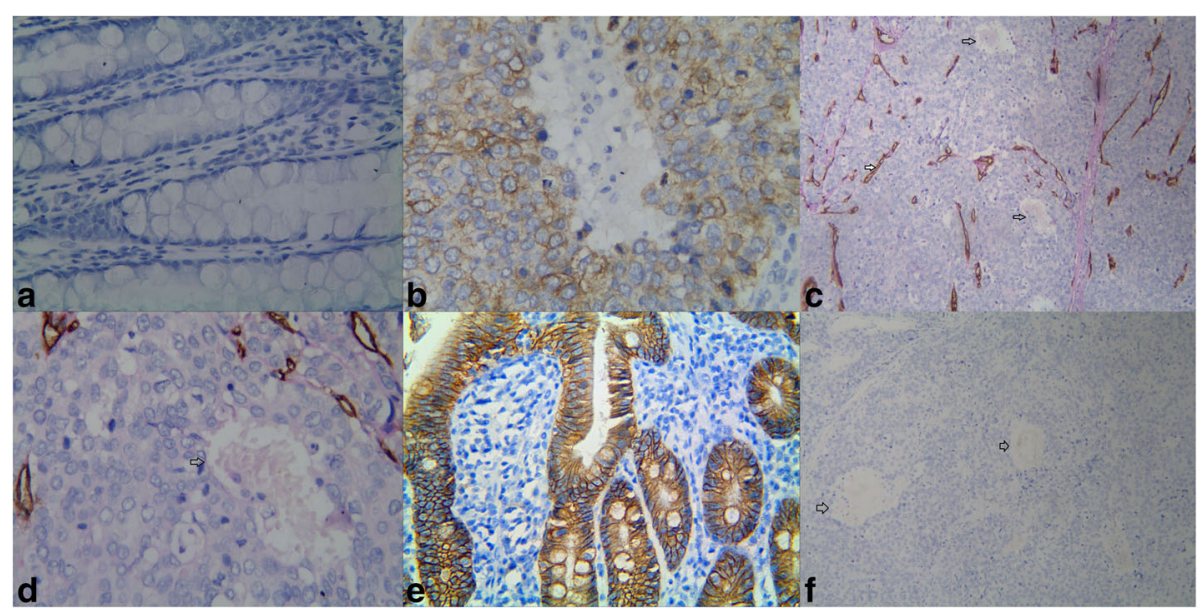

Fig. 1 Immunostaining of ALDH1, or VM or KAI1 in CRC or the control tissue. a Negative staining ALDH1 in the control tissue (400 magnification); b Positive staining of ALDH1 in the cytoplasm of cancer cells (400 magnification); c Positive staining of VM in the colorectal carcinoma tissues (100 magnification, white arrow is VM structure, black arrow is microvessel); d Positive staining of VM in the colorectal carcinoma tissues (400 magnification, white arrow is VM structure); e Positive staining of KAl1 in the membrane of control tissues (400 magnification); $\mathbf{f}$ Negative staining of KAl1 in the colorectal carcinoma tissues (100 magnification, Fig. b, c, d, f are serial sections) 


\section{Evaluation of staining}

Immunotaining findings were explained semi-quantitatively by two independent pathologists who were blind to the clinical, pathological and follow-up data. To avoid the intratumoral heterogeneity of antibodies expression, ten representative areas at high-power-fields (HPF) from different areas of each CRC's section were detected. immunohistochemistry results were counted according to the extent and intensity. The immunostaining intensity scores were graded as follows: 0 , none; 1 , weak; 2 , moderate; and 3, strong. The immunostaining extent scores were graded as follows: $1,<11 \% ; 2,11-50 \%$; $3,51-75 \%$; and $4,>75 \%$. Then, the intensity and extent scores were multiplied to reach a final score that ranged from 0 to 12 . The scores $\geq 3$ was considered positive. For samples that were positive for both
ALDH1 and KAI1, an average of the final score of each slide was taken.

\section{Statistical analysis}

Correlations between clinicopathological variables and ALDH1, VM, MVD or KAI1 were compared using Fisher's exact test or Chi-square test. The correlations among ALDH1, or VM, or MVD or KAI1 were compared using Spearman's coefficient test. The effects of ALDH1, VM, MVD or KAI1 on survival were determined using univariate and multivariate analyses. Independent prognostic factors were determined by the Cox regression model for multivariate analysis. The Kaplan-Meier method with log-rank test for univariate overall survival analysis was used to assess the correlation between ALDH1+, VM+, MVD+ or KAI1+ and

Table 2 The correlation between ALDH1, or VM, or MVD or KAI1 and clinicopathological characteristics in colorectal carcinoma

\begin{tabular}{|c|c|c|c|c|c|c|c|c|c|c|c|c|}
\hline \multirow[t]{2}{*}{ Variable } & \multicolumn{2}{|l|}{ ALDH1 } & \multirow[t]{2}{*}{$P$} & \multicolumn{2}{|l|}{ VM } & \multirow[t]{2}{*}{$P$} & \multirow{2}{*}{$\frac{\text { MVD }}{\text { Mean F }}$} & & \multirow[t]{2}{*}{$P$} & \multicolumn{2}{|l|}{ KAI1 } & \multirow[t]{2}{*}{$P$} \\
\hline & Negative & Positive & & Negative & Positive & & & & & Negative & Positive & \\
\hline Gender & & & 0.805 & & & 0.742 & & 0.539 & 0.464 & & & 0.590 \\
\hline Male & 31 & 89 & & 77 & 43 & & $21.4 \pm 5.8$ & & & 80 & 40 & \\
\hline Female & 23 & 61 & & 52 & 32 & & $20.8 \pm 5.7$ & & & 59 & 25 & \\
\hline Age (years) & & & 0.150 & & & 0.948 & & 1.074 & 0.301 & & & 0.579 \\
\hline$<60$ & 17 & 64 & & 51 & 30 & & $21.7 \pm 6.3$ & & & 57 & 24 & \\
\hline$\geq 60$ & 37 & 86 & & 78 & 45 & & $20.8 \pm 5.4$ & & & 82 & 41 & \\
\hline Size (cm) & & & 0.629 & & & 0.508 & & 0.062 & 0.804 & & & 0.780 \\
\hline$<5.0$ & 30 & 89 & & 73 & 46 & & $21.1 \pm 6.2$ & & & 82 & 37 & \\
\hline$\geq 5.0$ & 24 & 61 & & 56 & 29 & & $21.3 \pm 5.2$ & & & 57 & 28 & \\
\hline Location & & & 0.066 & & & 0.324 & & 0.606 & 0.437 & & & 0.891 \\
\hline Rectum & 22 & 83 & & 63 & 42 & & $21.5 \pm 5.7$ & & & 72 & 33 & \\
\hline Colon & 32 & 67 & & 66 & 33 & & $20.8 \pm 5.9$ & & & 67 & 32 & \\
\hline Grade & & & 0.555 & & & 0.364 & & 2.903 & 0.057 & & & 0.001 \\
\hline Well & 14 & 31 & & 28 & 17 & & $20.3 \pm 4.5$ & & & 20 & 25 & \\
\hline Moderate & 25 & 82 & & 72 & 35 & & $22.1 \pm 5.8$ & & & 80 & 27 & \\
\hline Poor & 15 & 37 & & 29 & 23 & & $20.0 \pm 6.4$ & & & 39 & 13 & \\
\hline Invasion & & & 0.024 & & & 0.002 & & 11.858 & 0.001 & & & 0.016 \\
\hline Subseroa & 37 & 76 & & 82 & 31 & & $19.9 \pm 4.7$ & & & 69 & 44 & \\
\hline Visceral peritoneum & 17 & 74 & & 47 & 44 & & $22.7 \pm 6.6$ & & & 70 & 21 & \\
\hline Distant metastasis & & & 0.006 & & & $<0.001$ & & 34.878 & $<0.001$ & & & 0.018 \\
\hline No & 53 & 123 & & 121 & 55 & & $2.3 \pm 5.1$ & & & 114 & 62 & \\
\hline Yes & 1 & 27 & & 8 & 20 & & $26.7 \pm 6.7$ & & & 25 & 3 & \\
\hline LNM & & & 0.002 & & & $<0.001$ & & 14.053 & $<0.001$ & & & $<0.001$ \\
\hline No & 42 & 80 & & 92 & 30 & & $20.0 \pm 4.9$ & & & 70 & 52 & \\
\hline Yes & 12 & 70 & & 37 & 45 & & $22.9 \pm 6.4$ & & & 69 & 13 & \\
\hline TNM stage & & & 0.024 & & & $<0.001$ & & 34.116 & $<0.001$ & & & $<0.001$ \\
\hline land II & 40 & 85 & & 100 & 25 & & $19.4 \pm 4.3$ & & & 67 & 58 & \\
\hline III and IV & 14 & 65 & & 29 & 50 & & $23.9 \pm 6.7$ & & & 72 & 7 & \\
\hline
\end{tabular}


clinicopathological variables using SPSS 19.0 software for Windows (Chicago, IL). A value of $P<0.05$ was defined as statistically significant.

\section{Results}

\section{Correlations between ALDH1, VM, MVD or KAI1 and} clinicopathological variables

To assess the contributions of ALDH1, VM, MVD and KAI1 to CRC, the results thereof were immunohistochemically assessed for both CRC and normal colorectal mucosa tissue samples. These data were then compared to the clinicopathological variables. The positive rate of ALDH1 expression in the CRC samples (73.5\%, 150/204) was significantly higher than that in the control normal tissues $(6.9 \%, 14 / 204 ; P<0.001$; Fig. $1 \mathrm{a}$ and $\mathrm{b})$. The positive expression rate of ALDH1 in CRC was positively correlated with tumor invasion, lymph node metastasis, distant metastasis and TNM stage, but not with patients age, gender, tumor size, grade or location (Table 2).
Similar to ALDH1, the positive rate of VM (Small vessel-like lumen in CRC that were PAS-positive but CD34-negative were to be VM. The VM channels pattern included linear, tubular, and network and so on.) was significantly higher in CRC (36.8\%, 75/204) than that in the control tissues $(0 \%, 0 / 204 ; P<0.001$, Fig. 1c and d). The positive rate of VM in CRC was positively correlated with tumor invasion, LNM, distant metastasis and TNM stage, but not patients age, gender, tumor size, grade or location (Table 2). And the positive staining of MVD scores were found to be significantly correlated with tumor invasion, LNM, distant metastasis and TNM stage in CRC. However, the scores of MVD were no significant association with patient age, gender, tumor size, tumor grade and location (Table 2).

The positive rate of KAI1 expression was significantly lower in CRC tissues $(31.9 \%, 65 / 204)$ than that in control normal tissues $(98.0 \%, 200 / 204 ; P<0.001$, Fig. 1e and $\mathrm{f}$ ). The positive rate of KAI1 expression

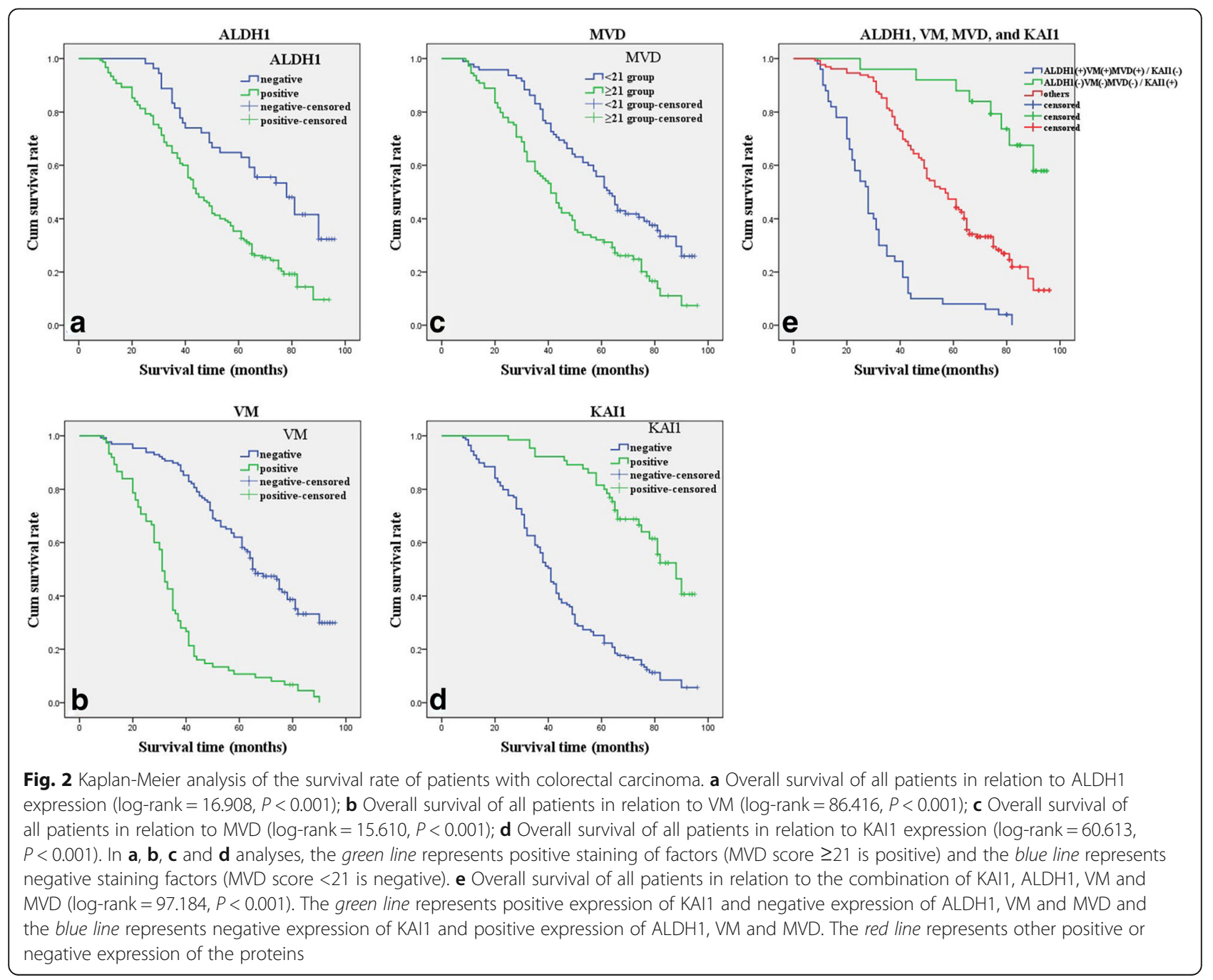


was inversely correlated with tumor grade, invasion, LNM, distant metastasis and TNM stage. No correlation was found between KAI1 expression and patients age, gender, tumor size or location (Table 2).

\section{Univariate and multivariate analysis}

Follow-up data showed that OS time was significantly shorter in CRC patients with positive expression of ALDH1 (47.1 \pm 22.4 months) compared with those with ALDH1-negative $(64.3 \pm 21.9$ months; $\log$-rank $=16.908$, $P<0.001$; Fig. 2a). Similarly, the OS time of VM-positive patients (34.7 \pm 19.0 months) was significantly lower than those of VM-negative patients $(61.5 \pm 20.0$ months; logrank $=86.416, P<0.001$; Fig. 2 b). The OS time of MVDpositive (the mean score of MVD is $21.2 \pm 5.8$, so MVD score $\geq 21$ is considered positive, MVD score $<21$ is considered negative) patients (44.9 \pm 22.8 months) was significantly shorter than those who were MVD-negative group $(59.4 \pm 21.9$ months; log-rank $=15.610, P<0.001$; Fig. 2c). The OS time of KAI1-positive patients (70.4 \pm 16.1 months) was significantly longer than those who were KAI1-negative ( $42.9 \pm 21.2$ months; log-rank $=60.613, P<$ 0.001; Fig. 2d). The combination of KAI1 negative expression and positive expression of ALDH1, VM and MVD had a poorer prognosis than did the reverse combination (log-rank $=97.184, P<0.001$; Fig. 2 e). In the univariate analysis, OS time was significantly correlated with clinicopathological variables, including invasion $(P=0.002$, logrank $=9.604)$, LNM $(P<0.001$, log-rank $=19.908)$, and TNM stage $(P<0.001$, log-rank $=53.120)($ Table 3$)$

Multivariate analysis suggested that ALDH1 and KAI1 positive expression, VM, invasion, as well as TNM stage, were independent prognostic indicators for CRC (Table 4).

\section{Association among ALDH1, VM, MVD and KAI1 in CRC}

Spearman correlation coefficient analysis indicated a negative association between the positive expression of KAI1 and that of ALDH1 $(r=-0.305, P<0.001)$, or VM $(r=-0.369, P<0.001)$, or MVD $(r=-0.458, P<0.001)$. Expression of ALDH1 and that of VM $(r=0.181, P=$ $0.010)$, and MVD scores $(r=0.242, P<0.001)$ were positively correlated, as were VM and MVD scores $(r=0.386$, $P<0.001$; Table 5).

\section{Discussion}

CRC is a highly heterogeneous tumor. This heterogeneity may influence the reproducibility of biomarker assessment $[38,39]$. So, prognostic role of candidate biomarkers should be thoroughly assessed to guarantee their validity. ALDH1, an enzyme related to vitamin A metabolism, is a CSC biomarker in various cancers [11-14]. In this study, We found that ALDH1 expression was significantly correlated with tumor invasion, LNM, distant metastasis and TNM stage. Furthermore,
Table 3 Results of univariate analyses of overall survival (OS) time

\begin{tabular}{|c|c|c|c|c|}
\hline Variable & $n$ & Mean OS (months) & Log-rank & $P$ value \\
\hline ALDH1 & & & 16.908 & $<0.001$ \\
\hline Negative & 54 & $64.3 \pm 21.9$ & & \\
\hline Positive & 150 & $47.1 \pm 22.4$ & & \\
\hline VM & & & 86.416 & $<0.001$ \\
\hline Negative & 129 & $61.5 \pm 20.0$ & & \\
\hline Positive & 75 & $34.7 \pm 19.0$ & & \\
\hline MVD & & & 15.610 & $<0.001$ \\
\hline$<21$ group & 95 & $59.4 \pm 21.9$ & & \\
\hline$\geq 21$ group & 109 & $44.9 \pm 22.8$ & & \\
\hline KAl1 & & & 60.613 & $<0.001$ \\
\hline Negative & 139 & $42.9 \pm 21.2$ & & \\
\hline Positive & 65 & $70.4 \pm 16.1$ & & \\
\hline Gender & & & 0.174 & 0.677 \\
\hline Male & 120 & $53.5 \pm 21.9$ & & \\
\hline Female & 84 & $49.0 \pm 25.5$ & & \\
\hline Ages (year) & & & 0.063 & 0.802 \\
\hline$<60$ & 81 & $51.9 \pm 23.3$ & & \\
\hline$\geq 60$ & 123 & $51.5 \pm 23.7$ & & \\
\hline Size $(\mathrm{cm})$ & & & 0.392 & 0.531 \\
\hline $\begin{array}{l}<5.0 \\
\geq 5.0\end{array}$ & $\begin{array}{l}119 \\
85\end{array}$ & $\begin{array}{l}51.0 \pm 23.3 \\
52.5 \pm 23.8\end{array}$ & & \\
\hline Location & & & 2.610 & 0.106 \\
\hline Rectum & 105 & $49.7 \pm 24.5$ & & \\
\hline Colon & 99 & $53.7 \pm 22.3$ & & \\
\hline Grade & & & 1.266 & 0.531 \\
\hline Well & 45 & $55.4 \pm 24.7$ & & \\
\hline Moderate & 107 & $51.4 \pm 22.9$ & & \\
\hline Poor & 52 & $48.9 \pm 23.5$ & & \\
\hline Invasion & & & 9.604 & 0.002 \\
\hline Subserosa & 113 & $56.9 \pm 22.6$ & & \\
\hline Visceral peritoneum & 91 & $45.1 \pm 22.9$ & & \\
\hline Distant metastasis & & & 3.717 & 0.054 \\
\hline No & 176 & $53.4 \pm 23.2$ & & \\
\hline Yes & 28 & $40.8 \pm 22.7$ & & \\
\hline LNM & & & 19.908 & $<0.001$ \\
\hline No & 122 & $59.4 \pm 19.7$ & & \\
\hline Yes & 82 & $40.0 \pm 23.9$ & & \\
\hline TNM stage & & & 53.120 & $<0.001$ \\
\hline land II & 125 & $60.3 \pm 19.9$ & & \\
\hline III and IV & 79 & $37.9 \pm 22.2$ & & \\
\hline
\end{tabular}

Kaplan-Meier survival analysis showed that ALDH1positive CRC patients had significantly shorter OS than did ALDH1-negative patients. Our findings were consistent with previous studies in CRC [11, 40,41] suggesting 
Table 4 Results of multivariate analyses of overall survival (OS) time

\begin{tabular}{llllll}
\hline Variable & $\mathrm{B}$ & $\mathrm{SE}$ & $\mathrm{P}$ & $\mathrm{RR}$ & $95 \% \mathrm{Cl}$ \\
\hline Invasion & 0.362 & 0.180 & 0.044 & 1.436 & $1.010-2.042$ \\
TNM stage & 0.592 & 0.204 & 0.004 & 1.808 & $1.212-2.697$ \\
ALDH1 & 0.587 & 0.225 & 0.009 & 1.798 & $1.157-2.794$ \\
VM & 0.912 & 0.206 & $<0.001$ & 2.490 & $1.664-3.725$ \\
KAl1 & -1.196 & 0.253 & $<0.001$ & 0.302 & $0.184-0.497$ \\
\hline
\end{tabular}

that ALDH1 should be considered as a valuable biomarker for CRC.

VM should be involved in the process of progression and metastasis of various cancers [16, 19, 24-29], suggesting that VM should be considered as a potential candidate therapeutic target. In this study, We found that VM and MVD were positively related to tumor invasion, LNM, distant metastasis and TNM stage. Moreover, Kaplan-Meier survival analysis indicated that VM-positive or MVD-positive CRC patients had significantly shorter OS than did VM-negative or MVD-negative. These findings suggested that VM or MVD should be a useful biomarker for predicting progression and metastasis in CRC. Similar results are obtained from some other immunohistochemical studies which detected the metastatic and prognostic significance of VM in CRC patients [42-44].

KAI1 is extensively considered as a suppressor gene of tumor metastasis in various human cancers [30-35]. KAI1 can inhibit cell migration, differentiation, invasion and metastasis. In this study, we found that KAI1 expression was significantly lower in CRC tissues than that in the control tissues. And its positive expression as inversely associated with tumor grade, invasion, LNM, distant metastasis and TNM stage. Furthermore, KaplanMeier survival analysis showed that CRC patients with KAI1-positive expression had significantly longer survival time than did KAI1-negative patients. These findings suggested that down- or-lost regulation of KAI1 should promote CRC progression and metastasis, which are consistent with the previous studies [30-35, 45].
TNM stage provides therapeutic strategies for CRC patients, but not provides entirely information about CRC behavior. Therefore, it is urgent to find novel and effective biomarkers for predicting CRC patients progression, metastasis and prognosis. In this study, multivariate Cox model analysis showed that ALDH1+, $\mathrm{KAI}+, \mathrm{VM}+$ and tumor invasion, as well as TNM stage, are independent prognostic factors for CRC patients. The most common causes of cancer-related deaths in CRC are metastasis and recurrence. Our findings thus demonstrated that ALDH1, VM and KAI1 should be considered as reliable biomarker for $\mathrm{CRC}$, especially in predicting progression, metastasis and prognosis.

Furthermore, ALDH1 is a biomarker of CSC which should be involved in the initiation and progression of CRC. The niche where CSC reside is mainly composed of microvessles and microlymphatic vessels. Abnormal expression of ALDH1 may be involved in the initiation, development, invasion, metastasis of cancers [45, 46]. Some researchers found that CSC were capable of differentiation along tumor and endothelial cells [47, 48]. These findings demonstrated that these cells (tumor and endothelial cells) were derived from CSC, thus CSC also mimicked endothelial cells to form a vasculogenic-like network to convey nutrient and oxygen. In the same time, CSC were capable of differentiation along endothelial cells and stimulated angiogenesis in order to tumor growth and invasion. KAI1 could inhibit the process of epithelial-mesenchymal transition (EMT) to prevent angiogenesis [49]. KAI1 is a cell membrane protein that bind to ECM or adhesion. Thus, decreased expression of KAI1 lost its role of inhibiting tumor metastasis and angiogenesis. Overall, these findings suggested that there should be a complex association between ALDH1, VM, MVD and KAI1 in tumor progression and metastasis. Combined with the findings of this study, to some extent, we believed that the interaction of these biomarkers could reflect the biological behavior of CRC cells, thus providing a choice of therapeutic strategies target.

Table 5 Correlation among ALDH1, VM, MVD and KAI1 in CRC

\begin{tabular}{|c|c|c|c|c|c|c|c|c|c|c|c|c|}
\hline \multirow[t]{2}{*}{ Variable } & \multicolumn{2}{|l|}{$\mathrm{ALDH1}$} & \multirow[t]{2}{*}{$r$} & \multirow[t]{2}{*}{$P$} & \multicolumn{2}{|l|}{ VM } & \multirow[t]{2}{*}{$r$} & \multirow[t]{2}{*}{$P$} & \multicolumn{2}{|l|}{ MVD } & \multirow[t]{2}{*}{$r$} & \multirow[t]{2}{*}{$P$} \\
\hline & Negative & Positive & & & Negative & Positive & & & $<21$ group & $\geq 21$ group & & \\
\hline$\overline{A L D H 1}$ & & & & & & & 0.181 & 0.010 & & & 0.242 & $<0.001$ \\
\hline Negative & & & & & 42 & 12 & & & 36 & 18 & & \\
\hline Positive & & & & & 87 & 63 & & & 59 & 91 & & \\
\hline VM & & & 0.181 & 0.010 & & & & & & & 0.386 & $<0.001$ \\
\hline Negative & 42 & 87 & & & & & & & 79 & 50 & & \\
\hline Positive & 12 & 63 & & & & & & & 16 & 59 & & \\
\hline KAl1 & & & -0.305 & $<0.001$ & & & -0.369 & $<0.001$ & & & -0.458 & $<0.001$ \\
\hline Negative & 24 & 115 & & & 71 & 68 & & & 43 & 96 & & \\
\hline Positive & 30 & 35 & & & 58 & 7 & & & 52 & 13 & & \\
\hline
\end{tabular}




\section{Conclusions}

It is suggested that ALDH1 should play a critical role in the evolution of CRC. The combined detection of ALDH1, VM, MVD and KAI1 should be valuable as biomarkers for metastasis and thereby prognosis for CRC patients.

\section{Abbreviations}

AJCC: American Joint Committee on Cancer; ALDH1: Aldehyde dehydrogenase 1; Cl: Confidence intervals; CRC: Colorectal carcinoma; CSC: Cancer stem cells; EMT: Epithelial-mesenchymal transition; HR: Hazard ration; LNM: Lymph node metastasis; MVD: Microvessel density; OS: Overall survival; PAS: Periodic acid-Schiff; PBS: Phosphate buffered saline; RT: Room temperature; TNM: Tumor node metastasis; VM: Vasculogenic mimicry; WHO: World Health Organization

\section{Acknowledgments}

We thank the staff members at the Department of Pathology of the First Affiliated Hospital of Bengbu Medical College for assistance with the data search and project management.

\section{Funding}

This work was supported by the Nature Science Foundation of Anhui Province (No.1708085MH230) and the Nature Science Key Program of College and University of Anhui Province (No. KJ2017A224 and No. KJ2016A488) and Key projects of support program for outstanding young talents in Colleges and Universities of Anhui Province (No. gxyqZD2016160).

\section{Availability of data and materials}

The datasets during and/or analyzed during the current study are available from the corresponding author on reasonable requests.

\section{Author's contribution}

WSW, ZB and ZL carried out the design, analysis of pathology and drafted the manuscript. YL, GXM and SWQ carried out sample collection and coordination. WDN performed the immunohistochemical staining. All authors read and approved the manuscript.

\section{Competing interests}

The authors declare that they have no competing interests.

\section{Consent for publication}

Not applicable.

\section{Ethics approval and consent to participate}

All tissue samples were obtained with patients writing consent and the study was approved by the ethical committee of Bengbu Medical College and performed in accordance with the ethical guidelines of the Declaration of Helsinki.

\section{Publisher's Note}

Springer Nature remains neutral with regard to jurisdictional claims in published maps and institutional affiliations.

Received: 12 December 2016 Accepted: 13 April 2017 Published online: 21 April 2017

\section{References}

1. Torre LA, Bray F, Siegel RL, Ferlay J, Lortet-Tieulent J, Jemal A. Global cancer statistics, 2012. CA Cancer J Clin. 2015:65:87-108.

2. Center MM, Jemal A, Smith RA, Ward E. Worldwide variations in colorectal cancer. CA Cancer J Clin. 2009:59:366-78.

3. Zheng R, Zeng H, Zhang S, Chen T, Chen W. National estimates of cancer prevalence in China, 2011. Cancer Lett. 2015:370:33-8.

4. Ricci-Vitiani L, Lombardi DG, Pilozzi E, Biffoni M, Todaro M, Peschle C, DeMaria R. Identification and expansion of human colon cancer-initiating cells. Nature. 2007:445:111-5.
5. Park IH, Zhao R, West JA, Yabuuchi A, Huo H, Ince TA, Lerou PH, Lensch MW, Daley GQ. Reprogramming of human somatic cells to pluripotency with defined factors. Nature. 2008;451:141-6.

6. Yu J, Vodyanik MA, Smuga-Otto K, Antosiewicz-Bourget J, Frane JL, Tian S, Nie J, Jonsdottir GA, Ruotti V, Stewart R, Slukvin II, Thomson JA. Induced pluripotent stem cell lines derived from human somatic cells. Science. 2007 ; 318:1917-20.

7. Balic A, Dorado J, Alonso-Gómez M, Heeschen C. Stem cells as the root of pancreatic ductal adenocarcinoma. Exp Cell Res. 2012;318:691-704.

8. Kim IG, Lee JH, Kim SY, Kim JY, Cho EW. Fibulin-3 negatively regulates ALDH1 via c-MET suppression and increases c-radiation-induced sensitivity in some pancreatic cancer cell lines. Biochem Biophy Res Commun. 2014; 454:369-75.

9. Huo W, Du M, Pan X, Zhu X, Li Z. Prognostic value of ALDH1 expression in lung cancer: a meta-analysis. Int J Clin Exp Med. 2015:8(2):2045-51.

10. Druesne-Pecollo N, Tehard B, Mallet $Y$, Gerber M, Norat T, Hercberg S, Latino-Martel P. Alcohol and genetic polymorphisms: effect on risk of alcohol-related cancer. Lancet Oncol. 2009;10:173-80.

11. Singh S, Arcaroli J, Thompson DC, Messersmith W, Vasiliou V. Acetaldehyde and retinaldehyde-metabolizing enzymes in colon and pancreatic cancers. Adv Exp Med Biol. 2015:815:281-94.

12. Wang Y, Zhe H, Gao P, Zhang N, Li G, Qin J. Cancer stem cell marker ALDH1 expression is associated with lymph node metastasis and poor survival in esophageal squamous cell carcinoma: a study from high incidence area of northern China. Dis Esophagus. 2012;25:560-5.

13. Jiang F, Qiu Q, Khanna A, Todd NW, Deepak J, Xing L, Wang H, Liu Z, Su Y, Stass SA, Katz RL. Aldehyde dehydrogenase 1 is a tumor stem cellassociated marker in lung cancer. Mol Cancer Res. 2009:7:330-8.

14. Li X, Xu Q, Fu X, Luo W. ALDH1A1 overexpression is associated with the progression and prognosis in gastric cancer. BMC Cancer. 2014;14:705.

15. Preusser M, Heinzl H, Gelpi E, Schonegger K, Haberler C, Birner P, Marosi C, Hegi M, Gorlia T, Hainfellner JA. Histopathologic assessment of hot-spot microvessel density and vascular patterns in glioblastoma: poor observer agreement limits clinical utility as prognostic factors - a translational research project of the European Organization for Research and Treatment of Cancer Brain Tumor Group. Cancer. 2006:107:162-70.

16. Chen YS, Chen ZP. Vasculogenic mimicry: a novel target for glioma therapy. Chin J Cancer. 2014:33:74-9.

17. Vredenburgh JJ, Desjardins A, Herndon IIJE, Dowell JM, Reardon DA, Quinn JA, Rich JN, Sathornsumetee S, Gururangan S, Wagner M, Bigner DD, Friedman AH, Friedman HS. Phase II trial of bevacizumab and irinotecan in recurrent malignant glioma. Clin Cancer Res. 2007;13:1253-9.

18. Maniotis AJ, Folberg R, Hess A, Seftor EA, Gardner LM, Pe'er J, Trent JM, Meltzer PS, Hendrix MJ. Vascular channel formation by human melanoma cells in vivo and in vitro: vasculogenic mimicry. Am J Pathol. 1999;155:739-52.

19. Wu S, Yu L, Wang D, Zhou L, Cheng Z, Chai D, Ma L, Tao Y. Aberrant expression of CD133 in non-small cell lung cancer and its relationship to vasculogenic mimicry. BMC Cancer. 2012;12:535.

20. Shirakawa K, Kobayashi H, Heike Y, Kawamoto S, Brechbiel MW, Kasumi F, Iwanage T, Konishi F, Terada M, Wakasugi H. Hemodynamics in vasculogenic mimicry and angiogenesis of inflammatory breast cancer xenograft. Cancer Res. 2002;62:560-6.

21. Shirakawa K, Kobayashi H, Sobajima J, Hashimoto D, Shimizu A, Wakasugi $H$. Inflammatory breast cancer: vasculogenic mimicry and its hemodynamics of an inflammatory breast cancer xenograft model. Breast Cancer Res. 2003;5:136-9.

22. Ruf W, Seftor EA, Petrovan RJ, Weiss RM, Gruman LM, Margaryan NV, Seftor RE, Miyagi Y, Hendrix MJ. Differential role of tissue factor pathway inhibitors 1 and 2 in melanoma vasculogenic mimicry. Cancer Res. 2003;63:5381-9.

23. van der Schaft DW, Hillen F, Pauwels P, Kirschmann DA, Castermans K, Oude Egbrink MG, Tran MG, Sciot R, Hauben E, Hogendoorn PC, Delattre O, Maxwell PH, Hendrix MJ, Griffioen AW. Tumor cell plasticity in Ewing sarcoma, an alternative circulatory system stimulated by hypoxia. Cancer Res. 2005;65:11520-8.

24. Liu X, Wang JH, Li S, Li LL, Huang M, Zhang YH, Liu Z, Yang YT, Ding R, Ke YQ. Histone deacetylase 3 expression correlates with vasculogenic mimicry through the phosphoinositide3 -kinase/ERK-MMP-laminin5y2 signaling pathway. Cancer Sci. 2015;106:857-66

25. Zhang JT, Sun W, Zhang WZ, Ge CY, Liu ZY, Zhao ZM, Lu XS, Fan YZ Norcantharidin inhibits tumor growth and vasculogenic mimicry of human gallbladder carcinomas by suppression of the PI3-K/MMPs/Ln-5Y2 signaling pathway. BMC Cancer. 2014;14:193. 
26. Hu A, Huang JJ, Jin XJ, Li JP, Tang YJ, Huang XF, Cui HJ, Xu WH, Sun GB. Curcumin suppresses invasiveness and vasculogenic mimicry of squamous cell carcinoma of the larynx through the inhibition of JAK-2/STAT-3 signaling pathway. Am J Cancer Res. 2015;5:278-88.

27. Wang L, Lin L, Chen X, Sun L, Liao Y, Huang N, Liao W. Metastasisassociated in colon cancer-1 promotes vasculogenic mimicry in gastric cancer by upregulating Twist1/2. Oncotarget. 2015;6:11492-506.

28. Tang NN, Zhu H, Zhang HJ, Zhang WF, Jin HL, Wang L, Wang P, Hu GJ, Hao B, Shi RH. HIF-1ainduces VE-cadherin expression and modulates vasculogenic mimicry in esophageal carcinoma cells. World J Gastroenterol. 2014;20:17894-904.

29. Zhao N, Sun BC, Zhao XL, Wang Y, Meng J, Che N, Dong XY, Gu Q. Role of $\mathrm{BCl}-2$ and its associated miRNAs in vasculogenic mimicry of hepatocellular carcinoma. Int J Clin Exp Pathol. 2015;8:15759-68.

30. Dong JT, Lamb PW, Rinker-Schaeffer CW, Vukanovic J, Ichikawa T, Isaacs JT, Barrett JC. KAI1, a metastasis suppressor gene for prostate cancer on human chromosome 11p11.2. Science. 1995;268:884-6.

31. Takeda T, Hattori N, Tokuhara T, Nishimura Y, Yokoyama M, Miyake M. Adenoviral transduction of MRP-1/CD9 and KAl-1/CD82 inhibits lymph node metastasis in orthotropic lung cancer model. Cancer Res. 2007:67:1744-9

32. Wang $G$, Jiang $H$, Xu H, Sun $Q$, Zhou $Y$, Xiang $P$, Cheng $Z$, Zhang $Y$, Zhou $Y$, Guo Q, Xu S, Ma S, Chen Z. Clinical significance of KAl1/CD82 protein expression in nasopharyngeal carcinoma. Oncol Lett. 2015;9:1681-6.

33. Bienstock RJ, Barrett JC. KAl1, a prostate metastasis suppressor: prediction of solvated structure and interactions with binding partners; integrins, cadherins and cell-surface receptor proteins. Mol Carcinog. 2001;32:139-53

34. Miranti CK. Controlling cell surface dynamics and signaling: how CD82/KAl1 suppresses metastasis. Cell Signal. 2009;21:196-211.

35. Malik FA, Sanders AJ, Jiang WG. KAI-1/CD82, The molecule and clinical implication in cancer and cancer metastasis. Histol Histopathol. 2009:24:519-30.

36. Kumada T, Tsuneyama K, Hatta H, Ishizawa S, Takano Y. Improved 1-h rapid immunostaining method using intermittent microwave irradiation: practicability based on 5 years application in Toyama Medical and Pharmaceutical University Hospital. Mod Pathol. 2004;17:1141-9.

37. Yue WY, Chen ZP. Does vasculogenic mimicry exist in astrocytoma? J Histochem Cytochem. 2005:53:997-1002.

38. Lips EH, van Eijk R, de Graaf EJ, Doornebosch PG, de Miranda NF, Oosting J, Karsten T, Eilers PH, Tollenaar RA, van Wezel T, Morreau H. Progression and tumor heterogeneity analysis in early rectal cancer. Clin Cancer Res. 2008;14:772-81.

39. Koelzer VH, Herrmann P, Zlobec I, Karmitopoulou E, Lugli A, Stein U. Heterogeneity analysis of metastasis associated in colon cancer 1 (MACC1) for survival prognosis of colorectal cancer patients: a retrospective cohort study. BMC Cancer. 2015;15:160.

40. Zhou F, Mu YD, Liang J, Liu ZX, Chen HS, Zhang JF. Expression and prognostic value of tumor stem cell markers ALDH1 and CD133 in colorectal carcinoma. Oncol Lett. 2014;7:507-12.

41. Vogler T, Kriegl L, Horst D, Engel J, Sagebiel S, Schäffauer AJ, Kirchner T, Jung $A$. The expression pattern of aldehyde dehydrogenase 1 (ALDH1) is an independent prognostic marker for low survival in colorectal tumors. Exp Mol Pathol. 2012;92:111-7.

42. Qi L, Song W, Liu Z, Zhao X, Cao W, Sun B. Wnt3apromotes the vasculogenic mimicry formation of colon cancer via Wnt/B-catenin signal. Int J Mol Sci. 2015;16:18564-79.

43. Zhang S, Fu Z, Wei J, Guo J, Liu M, Du K. Peroxiredoxin 2 is involved in vasculogenic mimicry formation by targeting VEGFR2 activation in colorectal cancer. Med Oncol. 2015;32:414

44. Baeten $\mathrm{Cl}$, Hillen F, Pauwels P, de Bruine AP, Baeten CG. Prognostic role of vasculogenic mimicry in colorectal cancer. Dis Colon Rectum 2009:52:2028-35.

45. Cao YT, Li JH, Wang YT, Fu YW, Xu J. Serum ALDHA1 is a tumor marker for the diagnosis of non-small cell lung cancer. Tumori. 2014;100:214-8.

46. Huang EH, Hynes MJ, Zhang T, Ginestier C, Dontu G, Appleman H, Fields JZ, Wicha MS, Boman BM. Aldehyde dehydrogenase 1 is a marker for normal and malignant human colonic stem cell (SC) and tracks SC overpopulation during colon tumorigenesis. Cancer Res. 2009;69:3382-9.

47. Wang R, Chadalavad K, Wilshire J, Kowalik U, Hovinga KE, Geber A, Fligelman B, Leversha M, Brennan C, Tabar V. Glioblastoma stem-like cells give rise to tumour endothelium. Nature. 2010;468:829-33.
48. Soda Y, Marumoto T, Friedmann-Morvinski D, Soda M, Liu F, Michiue H, Pastorino S, Yang M, Hoffman RM, Kesari S, Verman IM. Transdifferentiation of glioblastoma cells into vascular endothelial cell. Proc Natl Acad Sci U S A. 2011;108:4274-80.

49. Zhou L, Yu L, Wu S, Feng Z, Song W, Gong X. Clinicopathological significance of KAl1 expression and epithelial-mesenchymal transition in non-small cell lung cancer. World J Surg Oncol. 2015;13:324.

\section{Submit your next manuscript to BioMed Central and we will help you at every step:}

- We accept pre-submission inquiries

- Our selector tool helps you to find the most relevant journal

- We provide round the clock customer support

- Convenient online submission

- Thorough peer review

- Inclusion in PubMed and all major indexing services

- Maximum visibility for your research

Submit your manuscript at www.biomedcentral.com/submit
Biomed Central 